\title{
Brevibacterium pityocampae sp. nov., isolated from caterpillars of Thaumetopoea pityocampa (Lepidoptera, Thaumetopoeidae)
}

Correspondence

İkbal Agah İnce

agah.ince@wur.nl

\author{
Hatice Katı, ${ }^{1}$ Ikbal Agah İnce, ${ }^{1,2} \ddagger$ Ismail Demir ${ }^{2}$ and Zihni Demirbağ ${ }^{2}$ \\ ${ }^{1}$ Giresun University, Faculty of Arts and Sciences, Department of Biology, 28049 Giresun, Turkey \\ ${ }^{2}$ Karadeniz Technical University, Faculty of Arts and Sciences, Department of Biology, 61080 \\ Trabzon, Turkey
}

The genus Brevibacterium was proposed by Breed (1957). While several Gram-positive, non-spore-forming, nonbranching rods were classified as members of the genus Brevibacterium, further chemotaxonomic studies showed that not all of these species are members of the genus. Subsequently, these species have been classified in different coryneform genera (Collins, 1992) and the description of the genus was emended to include only those species that correspond to the type species, Brevibacterium linens (Collins et al., 1980). In addition to B. linens, 40 species with validly published names were assigned to the genus Brevibacterium at the time of writing (http://www.bacterio. cict.fr/b/brevibacterium.html).

Brevibacteria have been isolated from diverse habitats such as milk products (Kollöffel et al., 1999), clinical specimens (Wauters et al., 2001), human body parts (McBride et al., 1993; Wauters et al., 2003, 2004), soil (Tang et al., 2008), sediment (Gavrish et al., 2004; Lee, 2006; Bhadra et al., 2008), brown algae (Ivanova et al., 2004), paintings (Heyrman et al., 2004), poultry (Pascual \& Collins, 1999) and marine

¥Present address: Laboratory of Virology, Wageningen University and Research Center, 6700 AP Wageningen, The Netherlands.

The GenBank/EMBL/DDBJ accession number for the $16 \mathrm{~S}$ rRNA gene sequence of strain $\mathrm{Tp}^{\mathrm{T}} 2^{\top}$ is EU484189.

A comparison of the fatty acid profile of strain $T p 12^{\top}$ and related type strains is available as supplementary material with the online version of this paper. environments (Lee, 2008). In the present study, strain $\mathrm{Tp} 12^{\mathrm{T}}$, a novel member of the genus Brevibacterium, was isolated from larvae of the pine processionary moth (Thaumetopoea pityocampa Denis \& Schiffermüller, 1775; Lepidoptera, Thaumetopoeidae). While many bacterial strains have been isolated from insects (Demir et al., 2002; Sezen et al., 2004, 2005, 2007; Yılmaz et al., 2006; Bahar \& Demirbağ, 2007), to our knowledge, the present report is the first time that a brevibacterium has been isolated from an insect.

T. pityocampa is one of the most harmful pests of pine species in Mediterranean countries including Turkey (İnce et al., 2007). T. pityocampa nests were collected from Scots pine (Pinus sylvestris L.) from the Middle Black Sea region of Turkey while screening the bacterial flora of the pest (Ince et al., 2008). Based on colony morphology and the colour of bacterial specimens removed from T. pityocampa larvae, 14 different isolates (Tp1-Tp14) were determined as members of the bacterial flora of the larvae (Ince et al., 2008). Taxonomic identification of these isolates was finalized by a polyphasic taxonomic approach. One of the isolates obtained, strain $\mathrm{Tp} 12^{\mathrm{T}}$, was clearly distinguished from the other isolates on the basis of some morphological, physiological and biochemical characteristics. Based on the current polyphasic study, strain $\mathrm{Tp} 12^{\mathrm{T}}$ represents a novel species of the genus Brevibacterium.

After macroscopic examination, dead, diseased and healthy larvae were distinguished and were sterilized in $70 \%$ 
ethanol for $1.5-2$ min to remove external contaminants and then washed twice with sterile distilled water (Lipa \& Wiland, 1972; Poinar \& Thomas, 1978; Osborn et al., 2002). Using standard aseptic techniques, the contents of surface-sterilized insect larvae were collected with a sterile injector and suspended in $5 \mathrm{ml}$ PBS ( $\mathrm{pH}$ 7.4). Serial dilutions of the suspension were spread on nutrient agar (Case \& Johnson, 1992) and the plates were incubated at $30{ }^{\circ} \mathrm{C}$ for $48-72 \mathrm{~h}$. At the end of the incubation period, discrete bacterial colonies were removed aseptically by using an inoculation loop, restreaked on nutrient agar and incubated aerobically for $24-48 \mathrm{~h}$. According to the colour and morphology of the colonies, isolates were separated and pure cultures were prepared from colonies. The isolates were identified by morphological, physiological, biochemical and molecular methods according to Palleroni (1986) and Kandler \& Weiss (1986). Finally, a selected colony of isolate $\mathrm{Tp} 12^{\mathrm{T}}$ was purified by subculturing on plates and the bacterium was identified by various conventional and molecular tests.

Tryptic soy agar (TSA) was used for determination of phenotypic and physiological characteristics of strain $\mathrm{Tp} 12^{\mathrm{T}}$. Colony and cell morphology were determined by direct and stereomicroscopic observations of single colonies grown for 24, 48, 72 and $120 \mathrm{~h}$. Gram staining was performed according to the procedure described by Claus (1992) and confirmed by the KOH string test (Murray et al., 1999). The $\mathrm{KOH}$ test result was compared with the positive control Pseudomonas aeruginosa ATCC 27853 and the negative control Staphylococcus aureus ATCC 25923. Cell motility was examined by the presence of turbidity throughout tubes of semi-solid medium (Leifson, 1960) and by light microscopy (Olympus model CX21).

Growth of strain $\mathrm{Tp} 12^{\mathrm{T}}$ was tested at $25,30,40,45$ and $50{ }^{\circ} \mathrm{C}$. The optimal growth temperature was $30{ }^{\circ} \mathrm{C}$. Salt tolerance was tested by using the following $\mathrm{NaCl}$ concentrations $(\mathrm{w} / \mathrm{v}): 0,3,5,10,15$ and $18 \%$. The $\mathrm{pH}$ range for growth was investigated between $\mathrm{pH} 4.0$ and 10.0 at intervals of $0.5 \mathrm{pH}$ units. The results were monitored after $72 \mathrm{~h}$ incubation at $30{ }^{\circ} \mathrm{C}$. Catalase activity was determined by the production of bubbles after the addition of $10 \mu \mathrm{l} 3 \%(\mathrm{v} / \mathrm{v}) \mathrm{H}_{2} \mathrm{O}_{2}$ onto single colonies. Oxidase activity was observed by oxidation of $N, N, N^{\prime}, N^{\prime}$-tetramethyl $p$-phenylenediamine with oxidase discs containing $N, N$-dimethyl $p$-phenylenediamine oxalate and $\alpha$-naphthol (Fluka). A well-isolated colony was spread with an inoculating loop onto an oxidase disc. The reaction was observed within 2 min at $25-30{ }^{\circ} \mathrm{C}$ and compared with positive control $P$. aeruginosa ATCC 27853 and negative control Escherichia coli ATCC 25922.

Some physiological properties were tested by using API 20E strips (bioMérieux). Results were scored after 5 days at $30{ }^{\circ} \mathrm{C}$. Differential phenotypic, biochemical and physiological properties of strain $\mathrm{Tp} 12^{\mathrm{T}}$ and related Brevibacterium type strains are given in Table 1. To determine the major fatty acids, fatty acid methyl esters
Table 1. Differential phenotypic characteristics of strain $\mathrm{Tp} 12^{\top}$ and its close phylogenetic neighbours

Strains: 1, strain Tp $12^{\mathrm{T}}$; 2, B. album YIM $90718^{\mathrm{T}}$ (data from Tang et al., 2008); 3, B. samyangense SST- $8^{\mathrm{T}}$ (Lee, 2006). +, Positive; $\mathrm{W}$, weakly positive; -, negative; ND, no data available. All three strains grow at $40{ }^{\circ} \mathrm{C}$, form circular colonies and test negative for urease and oxidase and positive for catalase.

\begin{tabular}{|lccc|}
\hline Characteristic & $\mathbf{1}$ & $\mathbf{2}$ & $\mathbf{3}$ \\
\hline Colony colour & Yellow & White & Yellow \\
Motility & - & + & + \\
Growth at: & & & \\
$25{ }^{\circ} \mathrm{C}$ & + & $\mathrm{ND}$ & + \\
$30{ }^{\circ} \mathrm{C}$ & + & $\mathrm{ND}$ & + \\
$45{ }^{\circ} \mathrm{C}$ & - & + & + \\
pH for growth & & & \\
$\quad$ Range & $6-10$ & $6-8$ & $6.1-10.1$ \\
$\quad$ Optimum & 8 & $\mathrm{ND}$ & $\mathrm{ND}$ \\
NaCl tolerance $(\%, \mathrm{w} / \mathrm{v})$ & 10 & 10 & $10^{*}$ \\
Fermentation of: & & & \\
$\quad$ D-Glucose & - & - & $\mathrm{W}$ \\
$\quad$ Sucrose & - & - & $\mathrm{W}$ \\
$\quad$ Melibiose & - & $\mathrm{ND}$ & $\mathrm{ND}$ \\
Utilization of citrate & - & $\mathrm{ND}$ & $\mathrm{ND}$ \\
Nitrate reduction & + & - & - \\
Gelatin hydrolysis & - & + & - \\
DNA G+C content & 69.8 & 70.7 & 70 \\
$\quad$ (mol\%) & & & \\
Source of isolation & Insect & Saline soil & Beach sediment \\
& & & \\
\hline
\end{tabular}

${ }^{\star}$ Weak growth at $15 \%(\mathrm{w} / \mathrm{v}) \mathrm{NaCl}$.

were extracted from strain $\mathrm{Tp} 12^{\mathrm{T}}$ and analysed by gas chromatography (Hewlett Packard 5890 II plus) and the Sherlock Microbial Identification System using version 4.10 of the TSBA40 library (Microbial ID). These analyses were kindly performed by Fikrettin Şahin (Yeditepe University, Istanbul, Turkey).

Extraction of genomic DNA and PCR amplification of the $16 \mathrm{~S}$ rRNA gene were done as described by İnce et al. (2008). DNA sequencing was performed at Macrogen Inc. (Seoul, Korea). A total of $1402 \mathrm{nt}$ of the $16 \mathrm{~S}$ rRNA gene sequence from strain $\mathrm{Tp} 12^{\mathrm{T}}$ were determined. $16 \mathrm{~S}$ rRNA gene sequence comparisons with entries in the updated GenBank and EMBL databases were performed with the FASTA and BLAST programs (Pearson, 1990; Altschul et al., 1990, 1997). Sequence alignments were performed with the program CLUSTAL W (EMBL European Bioinformatics Institute; http://www.ebi.ac.uk) and edited with the GeneDoc software (Nicholas et al., 1997).

Evolutionary relationships of closely related members of Brevibacterium were inferred using three tree-making algorithms: the neighbour-joining (Saitou \& Nei, 1987), maximum-likelihood (Felsenstein, 1981) and maximumparsimony (Fitch, 1971) methods. The relationships among taxa were coherent in all tree-making methods 
used. A phylogenetic tree was constructed using the neighbour-joining method (Fig. 1). The tree is drawn to scale, with branch lengths in the same units as those of the evolutionary distances used to infer the phylogenetic tree. Evolutionary distances were computed using the JukesCantor method (Jukes \& Cantor, 1969) and are in units of the number of base substitutions per site. The bootstrap consensus tree is taken to represent the evolutionary history of the taxa analysed (Felsenstein, 1985). Percentages of replicate trees in which the associated taxa clustered together in the bootstrap test (1000 replicates) are shown next to the branches (Felsenstein, 1985). All positions containing gaps and missing data were eliminated from the dataset (complete deletion option). There were a total of 778 positions in the final dataset. Phylogenetic analyses were conducted in MEGA4 (Tamura et al., 2007).

The cellular fatty acids of strain $\mathrm{Tp} 12^{\mathrm{T}}$ were predominantly of the branched type, with anteiso- $\mathrm{C}_{15: 0}$ and anteiso- $\mathrm{C}_{17: 0}$ accounting for more than $90 \%$ of the total cellular fatty acids. Other fatty acids included iso- $\mathrm{C}_{15: 0}(4.8 \%)$ and iso$\mathrm{C}_{16: 0}(2.8 \%)$. A comparison of the cellular fatty acid contents of strain $\mathrm{Tp} 12^{\mathrm{T}}$, Brevibacterium album YIM $90718^{\mathrm{T}}$ and Brevibacterium samyangense SST- $8^{\mathrm{T}}$ is shown in Supplementary Table S1, available in IJSEM Online.

According to the comparison of $16 \mathrm{~S}$ rRNA gene sequences, the closest relatives of strain $\mathrm{Tp} 12^{\mathrm{T}}$ were $B$. album YIM $90718^{\mathrm{T}}$ and B. samyangense SST $-8^{\mathrm{T}}$, both showing $96 \%$ similarity. Levels of similarity between strain $\mathrm{Tp} 12^{\mathrm{T}}$ and the other recognized Brevibacterium species were lower than $96 \%$. In light of previous studies performed by Stackebrandt \& Goebel (1994) and Lee (2006), the 16S rRNA gene sequence comparisons indicate that the isolate can be assigned to a separate genospecies without the need for DNA-DNA hybridization experiments. Since the primary structure of the $16 \mathrm{~S}$ rRNA gene is easier to determine than hybridization between DNA strands, the strength of the sequence analysis is to recognize the level at which DNA pairing studies need to be performed, which certainly applies to similarities of $97 \%$ and higher (Stackebrandt \& Goebel, 1994). A tree depicting the phylogenetic position of strain $\mathrm{Tp} 12^{\mathrm{T}}$ within the genus Brevibacterium is shown in Fig. 1. Based on 16S rRNA gene sequence comparison, strain $\mathrm{Tp} 12^{\mathrm{T}}$ forms a distinct subclade with $B$. samyangense SST $-8^{\mathrm{T}}$.

Genomic DNA of strain $\mathrm{Tp} 12^{\mathrm{T}}$ was prepared for the determination of the $\mathrm{G}+\mathrm{C}$ content. The DNA base composition of strain $\mathrm{Tp} 12^{\mathrm{T}}$ was determined by HPLC and calculated according to the method of Mesbah et al. (1989) by the Deutsche Sammlung von Mikroorganismen und Zellkulturen as $69.8 \mathrm{~mol} \% \mathrm{G}+\mathrm{C}$, which is high in comparison with most other brevibacteria (Gruner et al., 1994). However, Lee (2006) indicated that the DNA G +C contents of the type strains of $B$. samyangense and B. album are 70.7 and $70.0 \mathrm{~mol} \%$, respectively, and the DNA G $+\mathrm{C}$ content of the type strain of Brevibacterium marinum was reported to be $71.4 \mathrm{~mol} \%$ (Lee, 2008).

Strain $\mathrm{Tp} 12^{\mathrm{T}}$ can also be discriminated from B. samyangense (Lee, 2006) and B. album (Tang et al., 2008) according to some biochemical and physiological properties. Significantly, strain $\mathrm{Tp} 12^{\mathrm{T}}$ cannot grow at $45{ }^{\circ} \mathrm{C}$, while $B$. samyangense and $B$. album can. While $B$. samyangense grows weakly in $15 \% \mathrm{NaCl}$, strain $\mathrm{Tp} 12^{\mathrm{T}}$ cannot grow at that concentration. Additionally, fermentation tests showed other differences between strain $\mathrm{Tp} 12^{\mathrm{T}}$ and B. samyangense and B. album isolates (Table 1).

In spite of the similarity to B. samyangense and B. album, strain $\mathrm{Tp} 12^{\mathrm{T}}$ can be readily differentiated from known species of the genus Brevibacterium with reference to some physiological and biochemical characteristics, cellular fatty acids, $16 \mathrm{~S}$ rRNA gene sequence and DNA G + C content. On the basis of the data obtained with our polyphasic taxonomic approach, strain $\mathrm{Tp} 12^{\mathrm{T}}$ merits recognition as a member of a novel species of the genus Brevibacterium, for which we propose the name Brevibacterium pityocampae sp. nov.

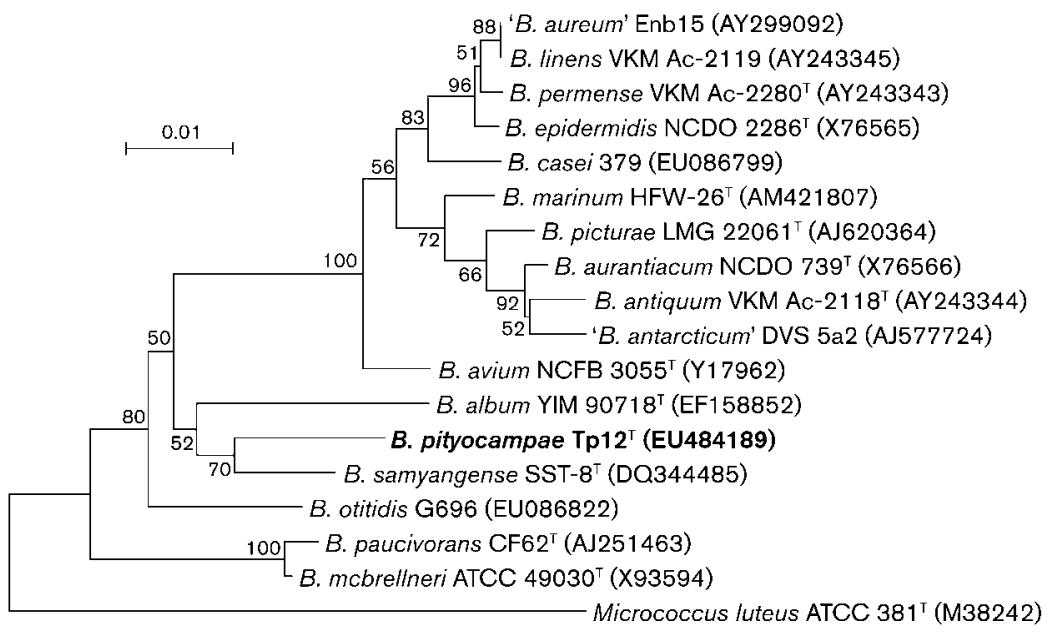

Fig. 1. Neighbour-joining tree based on $16 \mathrm{~S}$ rRNA gene sequences showing the phylogenetic position of Brevibacterium pityocampae sp. nov. Tp12 $2^{\top}$ within its phylogenetic neighbours in the genus Brevibacterium. Evolutionary distances for tree construction were calculated using the Jukes-Cantor coefficient. Numbers at nodes indicate percentages of bootstrap support based on a neighbour-joining analysis of 1000 iterated datasets. Micrococcus luteus ATCC $381^{\top}$ was defined as the outgroup. Bar, 1 substitution per 100 nucleotide positions. 


\section{Description of Brevibacterium pityocampae sp. nov.}

Brevibacterium pityocampae (pi.ty.o.cam'pae. L. fem. n. pityocampa a pine grub; L. fem. gen. n. pityocampae of a pine grub, referring to the isolation of the type strain from larvae of Thaumetopoea pityocampa).

Cells stain Gram-positive and are non-motile, non-sporeforming rods, $1.0 \mu \mathrm{m}$ long and $0.5 \mu \mathrm{m}$ wide. Catalasepositive and oxidase-negative. Colonies are yellow, circular and convex with entire margins. Growth is observed at 25$40{ }^{\circ} \mathrm{C}, \mathrm{pH}$ 6-10 (optimum $\mathrm{pH}$ 8) and $0-10 \% \mathrm{NaCl}(\mathrm{w} / \mathrm{v}$ ). No growth in $15 \% \mathrm{NaCl}(\mathrm{w} / \mathrm{v})$. Both the API $20 \mathrm{E}$ system and conventional tests show that arginine dihydrolase and acetoin production are negative. Nitrate is reduced to nitrite. Tests for $\beta$-galactosidase, lysine decarboxylase, ornithine decarboxylase, citrate utilization, $\mathrm{H}_{2} \mathrm{~S}$ production, urease, tryptophan deaminase, indole production and gelatinase and fermentation of D-glucose, D-mannitol, inositol, D-sorbitol, L-rhamnose, sucrose, melibiose, amygdalin and L-arabinose are negative. The fatty acid profile contains predominantly anteiso- $\mathrm{C}_{15: 0}$ and anteiso- $\mathrm{C}_{17: 0}$. The $\mathrm{G}+\mathrm{C}$ content of the type strain is $69.8 \mathrm{~mol} \%$.

The type strain is $\mathrm{Tp} 12^{\mathrm{T}}\left(=\mathrm{DSM} 21720^{\mathrm{T}}=\mathrm{NCCB}\right.$ $100255^{\mathrm{T}}$ ), isolated from healthy larvae of Thaumetopoea pityocampa from the Middle Black Sea region of Turkey.

\section{Acknowledgements}

This work was supported by the T. R. Prime Ministry State Planning Organization (21.111.004.1). The authors would like to thank Professor Dr Fikrettin Şahin (Yeditepe University, Istanbul, Turkey) for his help with the fatty acid methyl ester study.

\section{References}

Altschul, S. F., Gish, W., Miller, W., Myers, E. W. \& Lipman, D. J. (1990). Basic local alignment search tool. J Mol Biol 215, 403-410.

Altschul, S. F., Madden, T. L., Schäffer, A. A., Zhang, J., Zhang, Z. \& Miller, W. (1997). Gapped BLAST and PSI-BLAST: a new generation of protein database search programs. Nucleic Acids Res 25, 3389-3402.

Bahar, A. A. \& Demirbağ, Z. (2007). Isolation of pathogenic bacteria from Oberea linearis (Coleoptera: Cerambycidae). Biologia 62, 13-18.

Bhadra, B., Raghukumar, C., Pindi, P. K. \& Shivaji, S. (2008). Brevibacterium oceani sp. nov., isolated from deep-sea sediment of the Chagos Trench, Indian Ocean. Int J Syst Evol Microbiol 58, 57-60.

Breed, R. S. (1957). Family IX. Brevibacteriaceae Breed, 1953. In Bergey's Manual of Determinative Bacteriology, 7th edn, pp. 490-505. Edited by R. S. Breed, E. G. D. Murray \& N. R. Smith. London: Baillière, Tindall \& Cox.

Case, C. L. \& Johnson, T. R. (1992). Laboratory Experiments in Microbiology, 3rd edn. Menlo Park, CA: Benjamin/Cummings.

Claus, M. (1992). A standardized Gram staining procedure. World J Microbiol Biotechnol 8, 451-452.

Collins, M. D. (1992). The genus Brevibacterium. In The Prokaryotes, 2nd edn, vol. 2, pp. 1351-1354. Edited by A. Balows, H. G. Trüper, M. Dworkin, W. Harder \& K. H. Schleifer. New York: Springer.
Collins, M. D., Jones, D. R., Keddie, M. \& Sneath, P. H. A. (1980). Reclassification of Chromobacterium iodinum (Davis) in a redefined genus Brevibacterium (Breed) as Brevibacterium iodinum nom. rev.; comb. nov. J Gen Microbiol 120, 1-10.

Demir, i., Sezen, K. \& Demirbağ, Z. (2002). The first study on bacterial flora and biological control agent of Anoplus roboris (Sufr., Coleoptera). J Microbiol 40, 104-108.

Felsenstein, J. (1981). Evolutionary trees from DNA sequences: a maximum likelihood approach. J Mol Evol 17, 368-376.

Felsenstein, J. (1985). Confidence limits on phylogenies: an approach using the bootstrap. Evolution 39, 783-791.

Fitch, W. M. (1971). Toward defining the course of evolution: minimum change for a specific tree topology. Syst Zool 20, 406-416.

Gavrish, E. Y., Krauzova, V. I., Potekhina, N. V., Karasev, S. G., Plotnikova, E. G., Altyntseva, O. V., Korosteleva, L. A. \& Evtushenko, L. I. (2004). Three new species of brevibacteria, Brevibacterium antiquum sp. nov., Brevibacterium aurantiacum sp. nov., and Brevibacterium permense sp. nov. Mikrobiologiia 73, 218-215 (in Russian).

Gruner, E., Steigerwalt, A. G., Hollis, D. G., Weyant, R. S., Weaver, R. E., Moss, C. W., Daneshvar, M., Brown, J. M. \& Brenner, D. J. (1994). Human infections caused by Brevibacterium casei, formerly CDC groups B-1 and B-3. J Clin Microbiol 32, 1511-1518.

Heyrman, J., Verbeeren, J., Schumann, P., Devos, J., Swings, J. \& De Vos, P. (2004). Brevibacterium picturae sp. nov., isolated from a damaged mural painting at the Saint-Catherine chapel (Castle Herberstein, Austria). Int J Syst Evol Microbiol 54, 1537-1541.

İnce, i. A., Demir, i., Demirbağ, Z. \& Nalcacıoglu, R. (2007). A cytoplasmic polyhedrosis virus isolated from the pine processionary caterpillar, Thaumetopoea pityocampa. J Microbiol Biotechnol 17, 632637.

İnce, i. A., Katı, H., Yılmaz, H., Demir, i. \& Demirbağ, Z. (2008). Isolation and identification of bacteria from Thaumetopoea pityocampa Den. and Schiff. (Lep., Thaumetopoeidae) and determination of their biocontrol potential. World J Microbiol Biotechnol 24, 30053015.

Ivanova, E. P., Christen, R., Alexeeva, Y. V., Zhukova, N. V., Gorshkova, N. M., Lysenko, A. M., Mikhailov, V. V. \& Nicolau, D. V. (2004). Brevibacterium celere sp. nov., isolated from degraded thallus of a brown alga. Int J Syst Evol Microbiol 54, 2107-2111.

Jukes, T. H. \& Cantor, C. R. (1969). Evolution of protein molecules. In Mammalian Protein Metabolism, vol. 3, pp. 21-132. Edited by H. N. Munro. New York: Academic Press.

Kandler, O. \& Weiss, N. (1986). Regular, nonsporing Gram-positive rods. In Bergey's Manual of Systematic Bacteriology, vol. 2, pp. 12081209. Edited by P. H. A. Sneath, N. S. Mair, M. E. Sharpe \& J. G. Holt. Baltimore: Williams \& Wilkins.

Kollöffel, B., Meile, L. \& Teuber, M. (1999). Analysis of brevibacteria on the surface of Gruyère cheese detected by in situ hybridization and by colony hybridization. Lett Appl Microbiol 29, 317-322.

Lee, S. D. (2006). Brevibacterium samyangense sp. nov., an actinomycete isolated from a beach sediment. Int J Syst Evol Microbiol 56, 1889-1892.

Lee, S. D. (2008). Brevibacterium marinum sp. nov., isolated from seawater. Int J Syst Evol Microbiol 58, 500-504.

Leifson, E. (1960). Atlas of Bacterial Flagellation. London: Academic Press.

Lipa, J. J. \& Wiland, E. (1972). Bacteria isolated from cutworms and their infectivity to Agrotis spp. (Lepidoptera, Noctuidae). Acta Microbiol Pol B 4, 127-140. 
McBride, M. E., Ellner, K. M., Black, H. S., Clarridge, J. E. \& Wolf, J. E. (1993). A new Brevibacterium sp. isolated from infected genital hair of patients with white piedra. J Med Microbiol 39, 255-261.

Mesbah, M., Premachandran, U. \& Whitman, W. B. (1989). Precise measurement of the $\mathrm{G}+\mathrm{C}$ content of deoxyribonucleic acid by highperformance liquid chromatography. Int J Syst Bacteriol 39, 159-167.

Murray, P. R., Baron, E. J., Pfaller, M. A., Tenover, F. C. \& Yolken, R. H. (editors) (1999). Manual of Clinical Microbiology, 7th edn. Washington, DC: American Society for Microbiology.

Nicholas, K. B., Nicholas, H. B. \& Deerfield, D. W. (1997). GeneDoc: analysis and visualization of genetic variation. EMBnet News 4, 1-4.

Osborn, F., Berlioz, L., Vitelli-Flores, J., Monsalve, W., Dorta, B. \& Lemoine, V. R. (2002). Pathogenic effects of bacteria isolated from larvae of Hylesia metabus Crammer (Lepidoptera: Saturniidae). J Invertebr Pathol 80, 7-12.

Palleroni, N. J. (1986). Gram-negative aerobic rods and cocci. In Bergey's Manual of Systematic Bacteriology, vol. 1, p. 140. Edited by N. R. Krieg \& J. G. Holt. Baltimore: Williams \& Wilkins.

Pascual, C. \& Collins, M. D. (1999). Brevibacterium avium sp. nov., isolated from poultry. Int J Syst Bacteriol 49, 1527-1530.

Pearson, W. R. (1990). Rapid and sensitive sequence comparison with FASTP and FASTA. Methods Enzymol 183, 63-98.

Poinar, G. O., Jr \& Thomas, G. M. (1978). Diagnostic Manual for the Identification of Insect Pathogens. New York \& London: Plenum.

Saitou, N. \& Nei, M. (1987). The neighbor-joining method: a new method for reconstructing phylogenetic trees. Mol Biol Evol 4, 406-425.

Sezen, K., Demir, i. \& Demirbağ, Z. (2004). Studies of the bacterial flora as a biological control agent of the Agelastica alni L. (Coleoptera: Chrysomelidae). Biologia 59, 327-331.

Sezen, K., Demir, I., Katı, H. \& Demirbağ, Z. (2005). Investigations on the bacteria as potential biological control agent of summer chafer,
Amphimallon solstitiale L. (Coleoptera: Scarabaeidae). J Microbiol 43, 463-468.

Sezen, K., Demir, i. \& Demirbağ, Z. (2007). Identification and pathogenicity of entomopathogenic bacteria from common cockchafer, Melolontha melolontha (Coleoptera: Scarabaeidae). N Z J Crop Hort Sci 35, 79-85.

Stackebrandt, E. \& Goebel, B. M. (1994). Taxonomic note: a place for DNA-DNA reassociation and $16 \mathrm{~S}$ rRNA sequence analysis in the present species definition in bacteriology. Int J Syst Bacteriol 44, 846849.

Tamura, K., Dudley, J., Nei, M. \& Kumar, S. (2007). MEGA4: molecular evolutionary genetics analysis (MEGA) software version 4.0. Mol Biol Evol 24, 1596-1599.

Tang, S.-K., Wang, Y., Schumann, P., Stackebrandt, E., Lou, K., Jiang, C.-L., Xu, L.-H. \& Li, W.-J. (2008). Brevibacterium album sp. nov., a novel actinobacterium isolated from a saline soil in China. Int J Syst Evol Microbiol 58, 574-577.

Wauters, G., Charlier, J., Janssens, M. \& Delmée, M. (2001). Brevibacterium paucivorans sp. nov., from human clinical specimens. Int J Syst Evol Microbiol 51, 1703-1707.

Wauters, G., Avesani, V., Laffineur, K., Charlier, J., Janssens, M., Van Bosterhaut, B. \& Delmée, M. (2003). Brevibacterium lutescens sp. nov., from human and environmental samples. Int $J$ Syst Evol Microbiol 53, 1321-1325.

Wauters, G., Haase, G., Avesani, V., Charlier, J., Janssens, M., Van Broeck, J. \& Delmée, M. (2004). Identification of a novel Brevibacterium species isolate from humans and description of Brevibacterium sanguinis sp. nov. J Clin Microbiol 42, 2829-2832.

Yılmaz, H., Sezen, K., Katı, H. \& Demirbağ, Z. (2006). The first study on the bacterial flora of the European spruce bark beetle, Dendroctonus micans (Coleoptera: Scolytidae). Biologia 61, 679-686. 